\title{
Kulnun kennara og starfsaðstæður: Próun og samanburður við aðra opinbera sérfræðinga
}

\author{
Sif Einarsdóttir, Regína Bergdís Erlingsdóttir, \\ Amalía Björnsdóttir og Ásta Snorradóttir \\ Abstract Um höfundana About the authors $>$ Heimildir
}

Frá efnahagshruninu 2008 hefur niðurskurður fjármagns leitt til pess meðal annars að minna svigrúm hefur gefist til að takast á við brýn úrlausnarefni í skólastarfi. Vísbendingar eru um að líðan kennara hafi versnað frá árinu 2008 og pví er mikilvægt að kanna hvort breytingar hafi orðið á einkennum kulnunar frá fyrri rannsóknum meðal grunnskólakennara á árunum 1999 og 2005. Sami spurningalisti og notaður var í fyrri rannsóknum, Maslach Burnout Inventory (MBI-ES) var lagður fyrir 515 grunnskólakennara í Reykjavík. Konur voru 85\%, karlar 15\% og svarhlutfallið var 38\%. Einnig voru lagðir fyrir listar sem meta annars vegar örmögnunarröskun (The Karolinska Emotional Exhaustion Scale - KEDS) og hins vegar starfsaðstæður (Job Demands-Resource Scale - JDRS). Í ljós kom að einkenni kulnunar meðal grunnskólakennara hafa aukist frá pví fyrir hrun, einkum tilfinningaprot, en grunnskólakennarar meta starfsárangur enn nokkuð mikinn og finna varla til hlutgervingar gagnvart nemendum. Um 42\% grunnskólakennara mæta greiningarviðmiðum fyrir örmögnunarröskun samanborið við 31-38\% félagsmanna BHM. Hvað starfsaðstæður varðar meta grunnskólakennarar álag mikið en telja sig hafa tækifæri til að vaxa í starfi og fá stuðning frá stofnun, t.d. stjórnendum. Grunnskólakennarar finna til starfsöryggis en peir hafa ekki mikla möguleika á framgangi í starfi. Álag reyndist hafa sterkust tengsl við kjarnaeinkenni kulnunar, tilfinningaprot, í líkani Maslach og einnig örmögnunarröskun. Möguleikar til vaxtar í starfi og stuðningur stofnunar virðast hafa verndandi áhrif. Niðurstöður sýna að kulnun hefur aukist og mikilvægt er að huga að starfsaðstæðum grunnskólakennara, sérstaklega of miklu álagi. Ástæður pessa mikla álags geta verið margvíslegar en hugsanlega má rekja pær til hegðunarvanda í nemendahópi, skorts á viðeigandi úrræðum í málefnum nemenda sem veita parf sérstakan stuðning, aukins foreldrasamstarfs og almenns virðingarleysis gagnvart kennarastarfinu í samfélaginu.

Efnisorð: Kulnun, grunnskólakennarar, starfsaðstæður, heilsa og vellíðan, örmögnunarröskun, opinberir sérfræðingar

\section{Inngangur}

Umræða um kulnun í starfi og veikindi starfsfólks henni tengd hefur verið í brennidepli hérlendis og hefur meðal annars snert kennarastéttina. Óviðunandi starfsaðstæður, langvarandi álag og streita getur leitt til kulnunar og orðið ástæða pess að kennarar hverfa frá störfum í lengri eða skemmri tíma eða leita sér annarra starfa. Á síðustu 18 mánuðum leituðu 208 kennarar til VIRK - starfsendurhæfingarsjóðs og 65\% peirra greindu frá bví að starfsprot/kulnun væri ein af ástæðum fjarveru peirra frá vinnu (Svandís Nína Jónsdóttir, munnleg heimild, 9. október 2019). 
Spáð hefur verið fækkun grunnskólakennara á næstu árum samhliða auknum nemendafjölda (Helgi Eiríkur Eyjólfsson og Stefán Hrafn Jónsson, 2017). Skúli Helgason o.fl. (2017) bentu á að ekki væri næg aðsókn í kennaranám og pó umsóknum um grunnskólakennaranám hafi fjölgaði um 200 á landinu öllu haustið 2019 (Mennta- og menningarmálaráðuneytið, 2019) pá er langt í frá að mönnun stéttarinnar sé tryggð. Meðalaldur grunnskólakennara hefur hækkað um rúm fjögur ár síðan um aldamót (Hagstofa Íslands, 2019a) og vísbendingar eru um að leiðbeinendum fari aftur fjölgandi eftir að ástand hafði batnað í mönnun í kjölfar efnahagskreppunnar 2008 (Hagstofa Íslands, 2019b). Efnahagshrunið 2008 hafði víðtækar afleiðingar fyrir starf grunnskóla sökum niðurskurðar á fjárframlögum sem hafði meðal annars áhrif á starfsaðstæður. Dannig hefur vanlíðan sem rekja má til starfsaðstæðna aukist frá hruninu og peirri próun hefur ekki verið snúið við (Guðbjörg Linda Rafnsdóttir og Hjördís Sigursteinsdóttir, 2016).

Markmiðið með pessari rannsókn er að kanna algengi kulnunar og örmögnunarröskunar (e. exhaustion disorder) hjá grunnskólakennurum og hvort slíkt tengist starfsaðstæðum peirra. Vegna breytinga á starfsaðstæðum í kjölfar hrunsins er mikilvægt að kanna stöðu pessara mála og yfirvofandi kennaraskortur gerir pað enn brýnna. Pá verður metið hvernig kulnun hefur próast frá pví að fyrstu rannsóknir meðal grunnskólakennara voru gerðar. Fyrri rannsóknir sýna að á milli áranna 1999 og 2005 dró lítillega úr kulnun meðal íslenskra grunnskólakennara (Anna Dóra Baldursdóttir og Valgerður Magnúsdóttir, 2007) en ekki eru nýrri sambærilegar athuganir fyrir hendi. Auk pess að kanna kulnun eru starfsaðstæður grunnskólakennara metnar með heildstæðari hætti í pessari rannsókn en áđur hefur verið gert hérlendis. Nýleg rannsókn meðal félagsmanna í Bandalagi háskólamanna - BHM (Dórey Dormar, 2018) leyfir einnig markvissan samanburð á örmögnunarröskun sambærilegra stétta hjá hinu opinbera.

\section{Kenningar um kulnun og starfsumhverfi}

Kulnun lýsir sér í tilfinningalegri og líkamlegri örmögnun og er afleiðing langvarandi streitu sem ekki hefur náđst að yfirvinna. Streituvakarnir geta tengst ýmsu í umhverfi einstaklinga, bæði í starfsumhverfi og í persónulegu lífi (Bianchi, Truchot, Laurent, Brisson og Schonfeld, 2014). Herbert Freudenberger (1974) og Christina Maslach (1976) komu fyrst fram með hugtakið kulnun í starfi á áttunda áratug síðustu aldar, en pau höfðu hvort í sínu lagi greint slíkt ástand meðal starfsfólks í umönnunarstörfum. Bæði töldu pau að kulnun í starfi tengdist fyrst og fremst störfum par sem grunnurinn er sambandið á milli pess sem veitir pjónustu og pess sem piggur hana. Dar af leiðandi einskorðuðust fyrstu athuganir á kulnun við umönnunar- og pjónustustörf. Rannsóknir beindust pó fljótt að kennarastéttinni pví að kennarastarfið er svipaðs eðlis, byggt á samskiptum pess sem veitir og pess sem piggur. Á seinni stigum var síðan farið að rannsaka kulnun meðal ýmissa annarra starfsstétta, óháð pví hvort störfin snúast mikið um samskipti af pessu tagi (Kristensen, Borritz, Villadsen og Christensen, 2005; Maslach, Leiter og Schaufeli, 2008).

Maslach var leiðandi í rannsóknum á starfstengdri kulnun sem hún skilgreindi út frá prem víddum; tilfinningaproti (e. emotional exhaustion), hlutgervingu (e. depersonalization) og dvínandi starfsárangri (e. reduced personal accomplishment) (Maslach, 1993). Tilfinningaprot lýsir sér í pví að einstaklingurinn upplifir mikla preytu, bæði andlega og líkamlega. Tilfinningaprot er jafnframt kjarninn í kulnun samkvæmt Maslach. Hlutgerving lýsir sér í neikvæðum viðhorfum til vinnunnar og í umönnunar- og pjónustustörfum kemur pað fram gagnvart skjólstæðingum, eins og t.d. nemendum. Hlutgervingu vill Maslach meina að starfsfólk virki sem vörn gegn tilfinningaproti til að fjarlægja sig aðstæðum sem valda streitu. Dvínandi persónulegur árangur fylgir beirri tilhneigingu að meta eigin árangur í starfi á neikvæðan hátt og er afleiðing langvarandi tilfinningaprots (Maslach, Jackson og Leiter, 1986; Maslach, 1993; Maslach, Schaufeli og Leiter, 2001; Maslach og Leiter, 2016).

Einstaklingar sem upplifa kulnun missa með tímanum getuna til að sinna starfi sínu af áhuga, pað leiðir til pess að peir ná ekki að afkasta eins miklu og áður og skuldbinding við starfið minnkar. 
Afleiðingarnar geta verið fjarvera frá vinnu og fyrirætlanir um að hætta störfum. Degar haldið er áfram að vinna, prátt fyrir kulnun, verður pað til pess að skilvirkni starfsfólks minnkar (Maslach o.fl., 2001; Maslach og Leiter, 2016). Í kenningu Maslach er gengið út frá pví að kulnun sé einkum og sér í lagi starfstengt fyrirbæri og afleiðing langvinnrar streitu sem tengist starfi. Рað eru pví vinnutengdir pættir sem spá fyrir um kulnun, og í peim efnum settu Maslach, Jackson og Leiter (1997) fram tilgátu um að pað væri samspil óhóflegra krafna og skorts á úrræðum sem hefði mest áhrif. Demerouti, Bakker, Nachreiner og Schaufeli (2001) próuðu síðar kenningarlegt líkan til að meta petta samspil, sem nefnist The Job Demands-Resources Model (JDR-líkanið). Rannsóknir hafa sýnt að vinnutengdir pættir spái fyrir um kulnun meðal starfsfólks, en starfskröfur hafi pó sterkara forspárgildi en skortur á úrræðum í starfi (Hakanen, Schaufeli og Ahola, 2008).

Dó að flestar rannsóknir sem gerðar hafa verið á kulnun í starfi hafi byggst á kenningu Maslach (Bianchi o.fl., 2014) hafa einnig komið fram önnur sjónarmið og gagnrýni á kenningu hennar. Dar má nefna að dregið er í efa að kulnun sé einungis að rekja til starfstengdra pátta og pá er bent á að jafnvel einstaklingar utan vinnumarkaðar geti haft einkenni sem svipar til kulnunar í kenningu Maslach (Kristensen o.fl., 2005). Auk pess hefur verið bent á að ekki er alltaf hægt að aðgreina afleiðingar streitu sem á uppruna sinn í vinnu frá afleiðingum streitu sem skapast utan vinnu (Bianchi o.fl., 2014). Í Svípjóð hefur örmögnunarröskun verið skilgreind sem sjúkdómur innan ICD-10 sem er alpjóðlegt flokkunarkerfi sjúkdóma og skyldra heilbrigðisvandamála. Örmögnunarröskun lýsir sér í svipuðum einkennum og kulnun og er afleiðing langvarandi streitu sem tengist vinnu og/eða persónulegum aðstæðum (Besér o.fl., 2014). Rannsóknir hafa sýnt fram á skyldleika kulnunar og örmögnunarröskunar pannig að 93\% samsvörun virðist vera milli peirra (Hasselberg, Jonsdottir, Ellbin og Skagert, 2014).

Í nýlegri íslenskri rannsókn sem náði til allra félagsmanna BHM var örmögnunarröskun könnuð og tengsl hennar við starfsaðstæður (Dórey Dormar, 2018). Tíðni örmögnunarröskunar meðal umönnunarstétta (félagsráðgjafa, sjúkrapjálfara, framhalds- og háskólakennara, sálfræðinga og ljósmæðra) var um 38\% og 31\% meðal annarra félagsmanna BHM (lögfræðinga, arkitekta, stjórnsýslustarfsmanna, geislafræðinga, bókasafnsfræðinga, náttúrufræðinga og hagfræðinga). Rímar petta við hugmyndir Maslach og fleiri um að fólki sé hættara við kulnun í störfum sem hverfast um samskipti við pjónustupega. Fram kom að tengsl starfskrafna og skorts á úrræðum við örmögnunarröskun voru álíka sterk. Dað gefur til kynna að vernd fáist með pví að huga vel að uppbyggingu starfsumhverfisins (Dórey Dormar, 2018).

\section{Starfsaðstæður og kulnun meðal kennara}

Ýmsir pættir hafa í erlendum rannsóknum verið tengdir einkennum kulnunar hjá kennurum. Par má nefna starfskröfur og skort á úrræðum í starfi, svo sem tækifærum til að vaxa og dafna, sem og lítið sjálfræði í starfi (Jackson og Rothman, 2005). Einnig hefur komið fram að skortur á félagslegum stuðningi (Kahn, Schneider, Jenkins-Henkelman og Moyle, 2006), viðvarandi tímapressa (Johnston, 2012; Skaalvik og Skaalvik, 2010), erfið samskipti við nemendur og/eða foreldra (Pyhältö, Pietarinen og Salmela-Aro, 2011) og áhugaleysi nemenda á námi (Geving, 2007) getur ýtt undir kulnun. Agavandamál og hegðunarvandi nemenda hafa lengi reynst kennurum erfið (Gold og Roth, 1993). Kvíði vegna erfiðleika við að stýra hegðun nemenda er ein algengasta ástæðan fyrir pví að kennarar hætta í starfi (Cangelosi, 2004) og safngreining Aloe, Shisler, Norris, Nickerson og Rinker (2014) sýndi fram á tengsl milli erfiðrar hegðunar og kulnunar hjá kennurum. Miklar kröfur eru gerðar til kennara sem takast purfa á við daglegar áskoranir í samskiptum við nemendur auk pess að vera í góðu samstarfi við foreldra og aðra starfsmenn skólans.

Í íslenskri rannsókn á kulnun grunnskólakennara árið 1999 studdist Anna Póra Baldursdóttir (2002) við prípáttakenningu Maslach (1993). Niðurstöður sýndu að tilfinningaprot mældist nokkurt en lítið var um að grunnskólakennararnir hlutgerðu nemendur sína og peim fannst starfsárangur sinn yfirleitt nokkuð góður. Pá höfðu 65\% grunnskólakennara velt fyrir sér að 
láta af störfum vegna álags, bágra kjara eða peirrar upplifunar að virðingu fyrir kennarastarfinu skorti úti í samfélaginu. Kulnun mældist meiri hjá peim sem höfðu áformað að hætta kennslu en öðrum, sér í lagi meðal peirra sem íhuguðu að hætta vegna álags. Í síðari rannsókn Önnu Đóru Baldursdóttur og Valgerðar Magnúsdóttur (2007), sem var gerð árið 2005, mældist tilfinningaprot og hlutgerving lítillega lægri en í rannsókninni frá 1999 og starfsánægja reyndist meiri. Pá kom í ljós að 72\% grunnskólakennaranna höfðu hugleitt að hætta kennslu, sem er bó nokkur aukning frá árinu 1999. Sömu pæettir og nefndir voru í fyrri könnun voru tengdir pví að vilja hætta í starfi, p.e. lág laun, álag í starfi og sú upplifun að virðingu skorti fyrir starfinu í samfélaginu. Tímapressa og hegðunarvandamál nemenda voru nefnd sem helstu álagspæettirnir.

Mikið samræmi er í niðurstöðum íslenskra rannsókna og peirra erlendu í páttum sem tengjast kulnun kennara. Vert er að skoða nánar nokkra pætti sem gætu verið ástæða pess álags sem fram kemur meðal íslenskra grunnskólakennara. Í skýrslu starfshóps um nýliðun og bæett starfsumhverfi grunnskólakennara í Reykjavík kemur fram að kennurum finnst t.d. of mikið af tíma peirra fara í vinnu tengda greiningum á vanda nemenda og skortur er á úrræðum fyrir nemendur með náms- eða hegðunarerfiðleika (Skúli Helgason o.fl., 2017). Auk pess eru ný námskrá, breytingar á námsmati og auknar kröfur um skráningar og upplýsingagjöf taldar auka álag.

Grunnskólum ber að mennta öll börn og tryggja peim nám sem hentar hverjum og einum í sínum heimaskóla - skóla án aðgreiningar eða skóla margbreytileikans (Lög um grunnskóla nr. 91/2008; Mennta- og menningarmálaráðuneyti, 2011). Nemendahópurinn hefur alltaf verið fjölbreyttur og nýir hópar bætast við. Til að mynda hefur hlutfall nemenda með erlent móðurmál hækkað úr 1,5\% árið 1998 í rúm 10\% árið 2018 (Hagstofa Íslands, 2019c). Vissulega má rekja hluta af álagi grunnskólakennara til pess að peir purfa að koma til móts við fjölbreyttari hóp nemenda en áður, bæði hvað varðar uppruna, námsgetu og hegðun.

Agi og bekkjarstjórnun virðist hvíla pyngra á íslenskum kennurum en kennurum í nágrannalöndunum. Íslenskir unglingastigskennarar upplifa pannig meiri truflandi hegðun og agavandamál í nemendahópi en starfssystkini peirra annars staðar á Norðurlöndum (Ragnar F. Ólafsson, 2019). Í rannsókn Snæfríðar Björgvinsdóttur og Önnu-Lindar Pétursdóttur (2014) meðal grunnskólakennara í níu skólum á höfuðborgarsvæðinu kom í ljós að peir töldu um fjórðung nemenda hegða sér illa og hafði helmingur grunnskólakennaranna velt fyrir sér að láta af störfum vegna slíkrar hegðunar. Í ljós komu skýr tengsl milli pess að grunnskólakennarar purftu að takast á við erfið hegðunarvandamál og einkenna tilfinningaprots, en par var stuðst við kvarða Maslach. Баð parf pví ekki að koma á óvart að pegar íslenskir grunnskólakennarar voru beðnir að meta pörf fyrir starfspróun, pá reyndist áhugi mestur á starfspróunarverkefnum tengdum kennslu nemenda með sérparfir og fræðslu um aga- og hegðunarvandamál (Ragnar F. Ólafsson og Júlíus K. Björnsson, 2009). Tíu árum seinna var pörfin talin mest á pjálfun kennslu í fjölmenningarlegu umhverfi eða fjöltyngdum nemendahópi, hegðun og stjórnun í kennslustofu og notkun á tölvu- og upplýsingatækni (Ragnar F. Ólafsson, 2019).

Í TALIS, alpjóðlegri rannsókn á viðhorfum og starfsaðstæðum kennara sem nær til 48 landa, er áberandi að færri grunnskólakennarar hér á landi en að meðaltali í öðrum pátttökulöndum telja að kennarastarfið sé mikils metið í pjóðfélaginu og ánægja með laun er talsvert minni en annars staðar á Norðurlöndum (Ragnar F. Ólafsson, 2019). Um 60\% grunnskólakennara voru ósammála pví að borin væri virðing fyrir kennurum í peirra sveitarfélagi (Ragnar F. Ólafsson og Júlíus K. Björnsson, 2009). Detta er áhyggjuefni pví eins og áđur sagði hafa lág laun og upplifun á lítilli virðingu fyrir starfinu verið tengd pví að vilja hætta í starfi (Anna Dóra Baldursdóttir og Valgerður Magnúsdóttir, 2007). Dessar rannsóknir sýna að starfsumhverfi kennara er flókið og margpætt samskipti valda álagi pannig að starfskröfur eru miklar og úrræðin duga mögulega ekki til mótvægis. Til að varpa betur ljósi á starfsaðstæður kennara er mikilvægt að nota pekkt líkön (t.d. JDR-líkanið) sem leyfa samanburð við starfsaðstæður annarra stétta. 


\section{Kulnun og kreppan}

Í umfjöllun um starfsaðstæður grunnskólakennara má heldur ekki gleyma niðurskurði sem fylgdi í kjölfar efnahagskreppunnar 2008 og tók sinn toll af starfsfólki, pó skólastarf í kjölfar efnahagshrunsins virðist að mestu hafa gengið sinn vanagang. Bent hefur verið á að starfsmenn á öllum skólastigum bjuggu við aukið álag í mörg ár eftir hrunið meðan dregið var úr fjárframlögum til skóla (Steinunn Helga Lárusdóttir, Anna Kristín Sigurðardóttir, Arna H. Jónsdóttir, Börkur Hansen og Guðný Guðbjörnsdóttir, 2015). Rannsóknir hafa einnig leitt í ljós að t.d. veikindafjarvistir sem starfsfólk skóla rak til vinnutengdra aðstæðna í kjölfar bankahrunsins haustið 2008 jukust á árunum 2010-2016 (Guðbjörg Linda Rafnsdóttir og Hjördís Sigursteinsdóttir, 2016).

Rannsóknir á starfsaðstæðum og kulnun meðal hópa sem starfa í skólakerfinu annarra en grunnskólakennara hafa verið gerðar eftir efnahagshrunið 2008. Í rannsókn Brynhildar Magnúsdóttur (2012) kom í ljós að almennt leið framhaldsskólakennurum vel í vinnunni og ekki var mikið um að peir upplifðu kulnun. Svipaðar niðurstöður fengust í rannsókn peirra Guðrúnar Ragnarsdóttur, Ásrúnar Matthíasdóttur og Jóns Friðriks Sigurðssonar (2010) en pau mátu starfsánægju og starfsumhverfi framhaldsskólakennara. Deir voru flestir ánægðir í vinnu sinni og fannst umhverfið og vinnuaðstæður yfirleitt góðar. Pó sagðist helmingur framhaldsskólakennaranna finna fyrir miklu álagi tengdu starfinu og voru par af leiðandi ekki eins ánægðir í vinnunni og peir sem fundu ekki fyrir pessu álagi. Í rannsókn meðal grunnog leikskólastjóra kom í ljós að 15\% grunnskólastjóra upplifðu starfstengda kulnun og 28\% leikskólastjóranna (Gerður Ólína Steinpórsdóttir, Amalía Björnsdóttir og Börkur Hansen, 2015) en í peirri rannsókn var notaður annar kvarði til að meta kulnun, eða Copenhagen Burnout Inventory.

Ekki er til rannsókn sem metur kulnun meðal grunnskólakennara eftir efnahagshrunið, en í könnun Sambands íslenskra sveitarfélaga og Félags grunnskólakennara (2012/2013) á starfsumhverfi grunnskólakennara kom í ljós að 77\% peirra fannst álag sem fylgdi starfinu hafa aukist síðustu fimm árin. Deir nefndu líka að minna væri um sérkennslu og að samskipti við forráðamenn nemenda hefðu aukist. Pó almennt sé viðurkennt að foreldrasamstarf bæti bæði námsárangur og aðlögun barna að skólum (Hattie, 2009; Jeynes, 2005) og jákvæð viðhorf til foreldra einkenni pá skóla par sem hegðunarvandi er lítill (Ingvar Sigurgeirsson og Ingibjörg Kaldalóns, 2006), pá getur samstarfið reynt á grunnskólakennara. Aðeins 15\% umsjónarkennara í rannsókn í 20 grunnskólum fannst samstarf við foreldra vera mjög auðvelt (Kristín Jónsdóttir og Amalía Björnsdóttir, 2014) og fundist hafa tengsl milli kulnunar og erfiðra samskipta við foreldra (Pyhältö o.fl., 2011).

\section{Viðfangsefni rannsóknarinnar}

Eins og hér hefur verið rakið bendir allt til pess að starfsaðstæður grunnskólakennara hafi versnað í kjölfar efnahagshrunsins og að aukið álag fylgi mögulega tíðari hegðunarvanda, fjölbreyttari nemendahópi og auknum kröfum, t.d. um foreldrasamstarf. Vísbendingar eru um að í kjölfar hrunsins hafi ekki verið svigrúm til að breyta starfsháttum grunnskóla til að mæta pessum aðstæðum og takast á við ný úrlausnarefni. Í ljósi rannsókna á starfsaðstæðum og pess sem fram hefur komið í nýlegum athugunum eftir hrun (t.d. Guðbjörg Linda Rafnsdóttir og Hjördís Sigursteinsdóttir, 2016) má búast við að kulnun hafi aukist frá pví að hún var síðast metin af Önnu Dóru og Valgerði árið 2005. Dar sem grunnskólakennarar hafa lýst yfir óánægju með kjör, peir upplifa skort á virðingu og peim hefur verið tíðrætt um álag í starfi er pví mikilvægt að leita svara við pví hvort örmögnunarröskun sé tíðari í hópi peirra en hjá félagsmönnum BHM. Eins og fram hefur komið í fyrri rannsóknum (Hakanen o.fl., 2008; Pórey Pormar, 2018) má telja að starfsaðstæður, bæði starfskröfur og skortur á úrræðum, tengist kulnun í starfi hjá grunnskólakennurum. 


\section{Aðferð}

Til að kanna kulnun og starfsaðstæður hjá grunnskólakennurum var spurningalisti sendur til félagsmanna í Félagi grunnskólakennara í Reykjavík haustið 2018. Par sem mikilvægt er að skoða próun kulnunar yfir tíma var stuðst við kulnunarkvarða Maslach fyrir grunnskólakennara sem var notaður í fyrri rannsóknum árin 1999 og 2005 (Anna Dóra Baldursdóttir, 2002; Anna Póra Baldursdóttir og Valgerður Magnúsdóttir, 2007). Samanburður á kulnun kennara og félagsmanna BHM (Dórey Dormar, 2018) var fenginn með pví að leggja einnig fyrir The Karolinska Exhaustion Disorder Scale (KEDS). Að lokum var Job Demands-Resources Scale (JDRS) sem metur starfskröfur og úrræði í starfi lagður fyrir.

\section{Pátttakendur}

Könnunin var send til alls 1340 félaga í Félagi grunnskólakennara í Reykjavík í öllum 39 grunnskólum sem borgin rekur. Í félaginu eru einnig náms- og starfsráðgjafar, leiðbeinendur og verkefnastjórar. Alls tóku 515 manns pátt og var svarhlutfallið 38\%. Sum netföng reyndust vera óvirk og einhverjir voru í leyfi en nákvæmar upplýsingar fengust ekki um fjölda peirra. Detta pýðir að svarhlutfallið er líklega vanmetið. Konur voru 85\% $(N=438)$ og karlar 15\% (N = 75) pátttakenda, tveir svöruðu ekki spurningunni um kyn. Kynjahlutföll eru í samræmi við hlutfall kvenna og karla í starfi grunnskólakennara á Íslandi (Hagstofa Íslands, 2018). Menntun pátttakenda var fjölbreytt og voru margir með fleiri en eina prófgrádu. Meirihluti, eða $60 \%$, var a.m.k. með B.Ed.-gráðu og um 32\% höfðu lokið meistaragráðu eða annarri háskólamenntun á framhaldsstigi. Flestir pátttakendur (79\%) voru í fullu starfi. Tafla 1 sýnir hvernig pátttakendur dreifast eftir starfssviði, starfsreynslu og á aldursstigi nemenda.

Tafla 1. Skipting pátttakenda eftir starfssviði, aldursstigi og starfsreynslu.

\begin{tabular}{lcc}
\hline & $N$ & Hlutfall \\
\hline Starfssvið & & \\
Umsjón & 297 & $58 \%$ \\
Almenn kennsla & 126 & $25 \%$ \\
Sérkennsla/náms- og starfsráðgjöf & 77 & $15 \%$ \\
Annað & 11 & $2 \%$ \\
Aldursstig & & \\
Yngsta stig (1.-4. bekkur) & 129 & $25 \%$ \\
Miðstig (5.-7. bekkur) & 96 & $19 \%$ \\
Unglingastig (8.-10. bekkur) & 121 & $23 \%$ \\
Fleiri en eitt aldursstig & 159 & $31 \%$ \\
Annað & 10 & $2 \%$ \\
Starfsreynsla & & \\
10 ár eða minna & 142 & $27 \%$ \\
11-20 ár & 189 & $37 \%$ \\
21 ár og meira & 184 & $36 \%$ \\
\hline
\end{tabular}

Meirihluti kennaranna hafði bekkjarumsjón með höndum en fjórðungur sinnti almennri kennslu og par voru meðal annarra list- og verkgreinakennarar. Meðalstarfsreynsla grunnskólakennaranna var 18 ár $(s f=11)$. Um priðjungur kenndi á fleiri en einu aldursstigi (31\%) og fæstir kenndu á miðstigi (19\%). Deir sem sinntu öðrum störfum, sérkennslu og náms- og starfsráðgjöf, voru tiltölulega fámennur hópur (2\%). 


\section{Mælitæki}

\section{Maslach Burnout Inventory - Educators Survey}

Maslach Burnout Inventory - Educators Survey (MBI-ES) er útgáfa af spurningalistanum Maslach Burnout Inventory sem er sérsniðin fyrir kennara (Maslach, Jackson og Schwab, 1986; Maslach o.fl., 1997). Hann var pýddur og notaður í rannsókn Önnu Póru og félaga (2002; 2007). Í spurningalistanum eru 22 staðhæfingar sem skiptast á prjá undirkvarða sem mæla tilfinningaprot (e. emotional exhaustion), hlutgervingu (e. depersonalization) og starfsárangur (e. personal accomplishment). Pátttakendur bregðast við staðhæfingum um líðan í starfi, t.d. „Mér finnst ég búin/n á pví andlega í pessu starfi“ og „Ég er preytt/ur pegar ég fer á fæetur á morgnana og parf að horfast í augu við enn einn vinnudaginn“, á sex punkta svarkvarða. Gildi kvarðans eru $0=$ aldrei, 1 = nokkrum sinnum á ári, $2=$ einu sinni í mánuði eða sjaldnar, $3=$ nokkrum sinnum í mánuði, 4 = einu sinni í viku, 5 = nokkrum sinnum í viku og 6 = á hverjum degi. Svör eru síðan lögð saman fyrir hvern undirkvarða. Staðhæfingar sem snúa að tilfinningaproti eru níu, fimm fjalla um hlutgervingu og spurningar sem snúa að starfsárangri eru átta (spönn hvers kvarða má sjá í töflu 2). (Maslach o.fl., 1986; Maslach o.fl., 1997). Hærri gildi á kvörðum sem mæla tilfinningaprot og hlutgervingu eru merki um meiri kulnun og lægri gildi á kvarðanum um starfsárangur tengjast meiri kulnun. Áreiðanleiki (Cronbach’s alfa) kvarðanna MBI-ES hefur mælst í bandarískum rannsóknum 0,88-0,90 fyrir tilfinningalega örmögnun, 0,74-0,76 fyrir hlutgervingu og 0,72-0,76 fyrir starfsárangur. Páttagreiningar hafa stutt priggja pátta líkanið og formgerð listans (Maslach o.fl., 1997).

\section{The Karolinska Exhaustion Disorder Scale}

The Karolinska Exhaustion Disorder Scale (KEDS) er stuttur spurningalisti sem metur örmögnunarröskun. Hann greinir á milli fólks sem upplifir preytu sem telst eðlileg og peirra sem eru örmagna. Hann skimar einnig fyrir starfsfólki sem er í áhættu með að próa örmögnunarröskun (Besér o.fl., 2014). Í listanum eru níu atriði og einkennin sem pau vísa til eru: „Einbeiting“, „Minni“, „Líkamlegt pol“, „Andlegt pol“, „Endurheimt/bati“, „Svefn“, „Skynfæri“, „,Kröfur“ og „Pirringur og reiði“. KEDS er svarað á sex punkta kvarða sem tekur gildi á bilinu 0-6, og eru atriðin lögð saman til að mynda eina heildarniðurstöðu. Annað hvert gildi er tengt lýsandi staðhæfingum pannig að við spurninguna „Hér vil ég biðja pig um að lýsa getu pinni til að muna eftir hlutum. Veltu pví fyrir pér hvort pú eigir erfitt með að muna nöfn, dagsetningar eða hversdagsleg erindi“ er t.d. 0 = ég man eftir nöfnum, dagsetningum og peim erindum sem ég parf að sinna og 6 = ég gleymi daglega einhverju sem skiptir máli eða einhverju sem ég purfti að gera. Greiningarviðmið fyrir örmögnunarröskun eru 19 stig af 54 mögulegum (Besér o.fl., 2014).

\section{The Job Demands-Resources Scale}

The Job Demands-Resources Scale (JDRS) er mælikvarði sem var próaður af Jackson og Rothmann (2005) byggður á kenningu Demerouti o.fl. (2001) um tengsl óhóflegra krafna og skorts á úrræðum í starfi (JDR-líkan). Hann var í fyrstu próaður til að kanna starfsaðstæður kennara en einnig hefur hann verið notaður til að kanna starfsumhverfi annarra starfsstétta (Jackson og Rothmann, 2005; Rothmann, Mostert og Strydom, 2006). Í JDRS eru 42 atriði, m.a. um álag sem fylgir starfinu, tækifæri til pess að læra, sjálfstæði í starfi, samband við yfirmann, launakjör og öryggi í starfi. Dæmi um spurningar eru „Vinnurðu undir tímapressu?“”, „Geturðu treyst á yfirmann pinn pegar pú lendir í erfiðleikum í starfi?“, „Finnst pér stofnunin greiða góð laun?“ og „Veitir starfið pér möguleika á sjálfstæði í hugsun og framkvæmd?“. Svarmöguleikar eru á fjögurra punkta kvarða, $1=$ aldrei og $4=$ alltaf. Spurningunum er skipt 1 fimm undirpæetti: Of mikið álag (e. overload) (8 atriði), Tækifæri til pess að vaxa og dafna (e. growth) (7 atriði), Stuðningur frá stofnuninni (e. organizational support) (18 atriði), Starfsóöryggi (e. job insecurity) (3 atriði) og Framgangur (e. advancement) (6 atriði). Atriði hvers undirkvarða eru lögð saman til að fá niðurstöður fyrir hvern peirra (fjölda atriða og spönn hvers kvarða má sjá í töflu 4). Áreiðanleiki kvarðanna í erlendum rannsóknum hefur reynst vera góður, eða Cronbach's alfa á bilinu 0,75 til 0,90 (Jackson og Rothmann, 2005; Rothmann o.fl., 2006). 


\section{Framkvæmd}

Rannsóknin var gerð í samstarfi við Félag grunnskólakennara og var rafræn könnun send á netföng félagsmanna. Ákveðið var að byrja á að meta kulnun kennara í einu sveitarfélagi árið 2018 og varð раð stærsta, Reykjavík, fyrir valinu. Engra persónugreinanlegra gagna var aflað, t.d. var ekki spurt út í aldur eða við hvaða skóla pátttakendur störfuðu. Pátttakendur voru ekki spurðir viðkvæmra spurninga í skilningi laga um persónuvernd og vinnslu persónuupplýsinga (nr. 90/2018). Ítrekunarpóstur var sendur til félagsmanna eftir að könnunin hafði verið opin í viku. Áður en könnunin var send út var hún forprófuð með bví að leggja hana fyrir nokkra starfandi kennara og leikskólakennara sem voru beðnir að gera athugasemd við atriði sem voru óljós, við uppsetningu könnunarinnar og til að mæla hversu langan tíma tók að svara könnuninni í heild. Smávægilegar orðalagsbreytingar voru gerðar í kjölfarið á örfáum atriðum í listanum sem notaður var í rannsókn Önnu Dóru. Dær eru ekki taldar hafa áhrif á merkingu peirra.

\section{Niðurstöður}

Kulnun var metin á premur undirpáttum Maslach og niðurstöður bornar saman við fyrri íslenskar rannsóknir. Hlutfall peirra sem náðu greiningarviðmiði örmögnunarröskunar var reiknað og borið saman við hlutfallið hjá öðrum sérfræðistéttum hjá hinu opinbera. Starfsaðstæður voru að lokum metnar á fimm undirpáttum og tengsl peirra við prjá pætti kulnunar og örmögnunarröskun könnuð.

\section{Kulnun kennara}

Í töflu 2 má sjá að tilfinningaprot mældist að meðaltali 21,9 stig af 54 mögulegum. Flestir pátttakendur völdu svarmöguleika 2 eða 3 í einstökum spurningum, sem merkir að peir upplifðu tilfinningar tengdar tilfinningaproti einu sinni til nokkrum sinnum í mánuði. Athyglisvert er að hlutgerving mældist lítil, en meðaltal heildarstiga pess páttar var um 4 af 30 mögulegum. Meðaltal á pættinum starfsárangur mældist hæst af undirpáttunum premur, en ólíkt hinum páttunum var par verið að meta jákvæða upplifun. Að jafnaði svöruðu pátttakendur að peir fyndu fyrir atriðum sem tengdust starfsárangri einu sinni í viku eða oftar. Petta er t.d. að peim fyndist peir hafa jákvæð áhrif á líf annarra í gegnum starf sitt og að peir hefðu áorkað einhverju mikilvægu í starfi sínu.

Tafla 2. Meðaltal og öryggisbil kulnunarpátta mælt með MBI-ES ( $N=515)$.

\begin{tabular}{lccccccc}
\hline $\begin{array}{l}\text { Undirkvarðar } \\
\text { (möguleg stig) }\end{array}$ & \multicolumn{3}{l}{ Heildarstig } & \multicolumn{3}{c}{ Meðaltal undirkvarða } & Áreiðanleiki \\
& $M$ & $S f$ & Öryggisbil & $M$ & $S f$ & Öryggisbil & \\
\hline Tilfinningaprot (0-54) & 21,9 & 11,4 & $20,96-22,95$ & 2,44 & 1,27 & $2,33-2,55$ & 0,89 \\
Hlutgerving (0-30) & 3,6 & 4,2 & $3,22-3,95$ & 0,72 & 0,84 & $0,65-0,79$ & 0,65 \\
Starfsárangur (0-48) & 37,0 & 6,1 & $36,48-37,54$ & 4,62 & 0,76 & $4,56-4,69$ & 0,66 \\
\hline
\end{tabular}

Dreifigreining (ANOVA) var notuð til að kanna hvort fram kæmi munur á premur undirpáttum kulnunar eftir kyni, starfsreynslu og tegund kennslu. Dátttakendum var skipt í fjóra hópa eftir pví hvort peir voru með umsjón, í almennri kennslu (par með talið list- og verkgreinar), sinntu sérkennslu eða náms- og starfsráðgjöf. Ekki kom fram marktækur munur á milli pessara hópa á neinum af pessum premur undirpáttum kulnunar og pví eru niðurstöður aðeins kynntar fyrir félagsmenn í heild. Karlar $(M=18,34)$ virðast finna fyrir minna tilfinningaproti en konur $(\mathrm{M}=$ $22,57), F(1,510)=3,91, p=0,049$. Dó hlutgerving nemenda sé vart merkjanleg meðal kennara pá virðast reyndir kennarar finna minnst fyrir slíku af öllum hópunum. Deir sem höfðu starfað í yfir 20 ár við kennslu mældust lægstir á pessum pætti $(M=2,91) F(2,511)=3,01, p=0,05$. 
Til að meta hvernig kulnun kennara hefur próast síðastliðna áratugi voru niðurstöðurnar bornar saman við rannsóknir Önnu Póru Baldursdóttur og félaga (Anna Póra Baldursdóttir, 2002; Anna Dóra Baldursdóttir og Valgerður Magnúsdóttir, 2007). Í fyrri rannsókninni voru pátttakendurnir úr 171 grunnskóla á 68 stöðum á landinu og fengust svör frá alls 350 pátttakendum. Svarhlutfall var betra en í pessari rannsókn, eða rúm 58\% (Anna Dóra Baldursdóttir, 2002). Síðari rannsóknin var gerð í tveimur stórum sveitarfélögum með alls 14 skólum en svör einungis notuð frá öðru peirra vegna dræmrar pátttöku í hinu sveitarfélaginu. Svarhlutfall var tæplega $70 \%$ og voru pátttakendur tæplega 190 talsins (Anna bóra Baldursdóttir og Valgerður Magnúsdóttir, 2007). Pví miður voru ekki gefnar nægar upplýsingar til að reikna mætti vikmörk í fyrri rannsóknum og pví ekki hægt að meta hvort um tölfræðilega marktæka breytingu er að ræða. Á mynd 1 má sjá breytingar á kulnun grunnskólakennara. Tilfinningaprot var svipad árin 1999 og 2005 og taldist pá vera lágt en hefur síðan pá aukist töluvert samkvæmt pessari rannsókn og telst nú vera miðlungs mikið (Maslach o.fl., 1986). Hlutgerving mælist svipuð á pessum premur tímapunktum og pað sama gildir um starfsárangur.

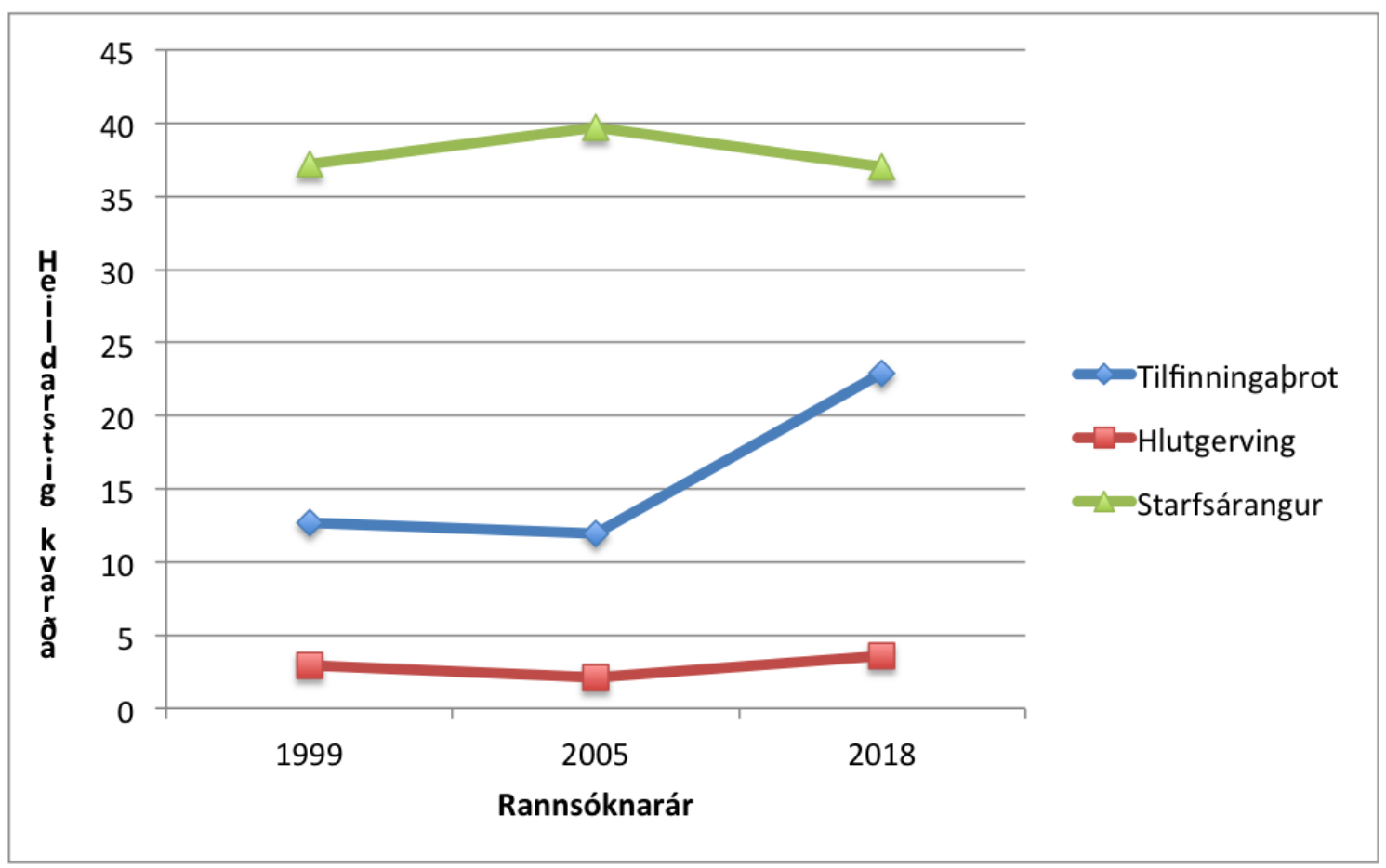

Mynd 1. Dróun priggja pátta kulnunar hjá grunnskólakennurum frá 1999 til 2018.

Til að bera saman kulnun kennara og annarra stétta sem vinna hjá hinu opinbera var örmögnunarröskun metin með KEDS. Eins og sjá má á töflu 3 er meðaltal kennara nærri 18 stig en 16 hjá félagsmönnum BHM, en greiningarviðmið örmögnunar eru við 19 stig. Öryggisbil meðaltalanna skarast ekki og eru grunnskólakennarar pví marktækt hærri í mælingu á örmögnunarröskun. Hlutfall grunnskólakennara sem ná greiningarmörkum er 42\% en var 31,3\% hjá félagsmönnum BHM sem ekki vinna í nánum samskiptum við skjólstæðinga (lögfræðingar, arkitektar, stjórnsýsla, geislafræðingar, bókasafnsfræðingar, náttúrufræðingar og hagfræðingar) og 37,5\% hjá félagsmönnum BHM sem vinna mikið með fólki, svo sem félagsráðgjöfum, sjúkrapjálfurum, framhalds- og háskólakennurum, sálfræðingum og ljósmæðrum. 
Tafla 3. Örmögnunarröskun meðal grunnskólakennara og félagsmanna BHM.

\begin{tabular}{lcccc}
\hline KEDS & \multicolumn{3}{c}{ Heildarstig } & 19 stig og yfir \\
& $M$ & $S f$ & Öryggisbil 95\% & $\%$ \\
\hline Grunnskólakennarar & 17,9 & 10,0 & $17,0-18,8$ & 42,0 \\
Félagsmenn BHM ${ }^{a}$ & 16,0 & 10,0 & $15,6-16,4^{\mathrm{b}}$ & $34,0^{\mathrm{c}}$ \\
& & & & \\
\multicolumn{1}{c}{ Í umönnun } & 17,1 & 10,3 & $16,4-18,1$ & 37,5 \\
\multicolumn{1}{c}{ Ekki í umönnun } & 15,1 & 9,6 & $14,5-15,7$ & 31,3 \\
\hline
\end{tabular}

${ }^{a}$ Úr rannsókn Póreyjar Dormar (2018); ' Endurreiknað byggt á töflu 1, bls. 16 í ritgerð Dóreyjar Dormar; 'Vegið meðaltal byggt á upplýsingum úr ritgerð Dóreyjar Dormar um hlutfall pátttakenda í umönnun og ekki í umönnun, bls. 11.

\section{Starfsaðstæður}

Að lokum var kannað hvernig starfsumhverfi tengdist kulnun hjá kennurum. Starfsumhverfi var metið með JDRS sem samanstendur af fimm undirpáttum. Niðurstöður JDRS eru kynntar hér fyrst í heild og síðan tengsl ólíkra pátta við undirpætti kulnunar. Í listanum eru spurningar sem snúa annaðhvort að starfskröfum (ofálag) eða úrræðum til að mæta starfskröfum (vöxtur í starfi, stuðningur, starfsöryggi, framgangur).

Í töflu 4 má sjá að grunnskólakennarar voru að jafnaði nálægt 3 af 4 mögulegum á pættinum sem mælir starfskröfur og er nefndur hér ofálag, sem gefur til kynna að peir fundu oft fyrir álagi í starfi. Athyglisvert er að pó kröfurnar hafi verið miklar kom í ljós að grunnskólakennarar mátu úrræði nánast jafn hátt og ofálag. Dað á bæði við um að fá tækifæri til að geta vaxið í starfi og stuðning frá stofnun, t.d. stjórnendum skólanna, en meðaltöl pessara priggja pátta eru næstum pau sömu. Ekki bar mikið á pví að pátttakendur fyndu fyrir óöryggi í starfi, niðurstöður úr peim undirpætti voru 1,5 pannig að pátttakendur hafa pví að jafnaði valið möguleikann ,aldrei“ eða „stundum“ við spurningunni um hvort peir hefðu áhyggjur af pví að missa starfið á næstunni. Á hinn bóginn gildir pað sama um spurninguna um tækifæri til framgangs í starfi, en pað pýðir að grunnskólakennarar telja sig ekki hafa mikla möguleika á slíku, sjá töflu 4. Heildarstig undirpátta JDRS eru í stórum dráttum í samræmi við niðurstöður Rothmann og félaga (2006) en í peirri rannsókn voru starfskröfur og úrræði ólíkra starfsstétta könnuð og einnig meðal kennara í Suður-Afríku. Áreiðanleiki kvarðanna er sambærilegur og hjá peim $(0,76-0,92)$ nema áreiðanleiki kvarðans framgangur er minni meðal íslenskra grunnskólakennara.

Tafla 4. Heildarstig, meðaltal og öryggisbil á mælingu á starfskröfum og úrræðum (JDRS).

\begin{tabular}{lccccccc}
\hline Undirkvarðar (möguleg stig) & \multicolumn{3}{c}{ Heildarstiga $^{\mathrm{a}}$} & \multicolumn{4}{c}{ Meðaltal } \\
& $M$ & $S f$ & $\begin{array}{c}\text { Öryggisbil } \\
95 \%\end{array}$ & $M$ & Sf & $\begin{array}{c}\text { Öryggisbil } \\
95 \%\end{array}$ & $\begin{array}{c}\text { Áreiðan- } \\
\text { leiki }\end{array}$ \\
\hline Ofálag (8-48) & 23,5 & 3,5 & $23,35-23,86$ & 2,9 & 0,4 & $2,91-2,98$ & 0,78 \\
Vöxtur í starfi (7-42) & 20,4 & 3,3 & $20,13-20,69$ & 2,9 & 0,5 & $2,88-2,96$ & 0,76 \\
Stuðningur frá stofnun & 53,2 & 9,6 & $52,33-53,99$ & 3,0 & 0,5 & $2,91-3,00$ & 0,92 \\
(18-118) 108) & 4,6 & 2,2 & $4,37-4,75$ & 1,5 & 0,7 & $1,46-1,58$ & 0,86 \\
Starfsóöryggi (3-18) & 9,7 & 2,4 & $9,45-9,87$ & 1,6 & 0,4 & $1,58-1,64$ & 0,65 \\
Framgangur (6-36) & &
\end{tabular}

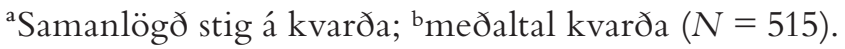

Dar sem tilfinningaprot er sá páttur í líkani Maslach sem mælist hæstur og hefur tekið mestum breytingum á síðastliðnum árum var ákveðið að skoða nánar hvaða pæettir í starfsumhverfinu tengjast tilfinningaproti og örmögnunarröskun (KEDS). Tengsl allra fimm pátta starfsaðstæðna innbyrðis og við tilfinningaprot auk örmögnunarröskunar má sjá í töflu 5. Ekki kemur á óvart að 
sjá má nokkuð mikla fylgni, $r=0,72$, milli tilfinningaprots og örmögnunarröskunar; pó listarnir byggist á ólíkum hugmyndum ná peir báđir yfir kjarnaeinkenni kulnunar. Fimm undirkvarðar starfsaðstæðna í JDRS-listanum sýna innbyrðis fylgni á bilinu 0,11-0,52.

Tafla 5. Fylgni milli pátta í starfsumhverfi, tilfinningaprots og örmögnunarröskunar.

\begin{tabular}{lrrrrrrr}
\hline & 1 & 2 & 3 & 4 & 5 & 6 & 7 \\
\hline 1. Tilfinningaprot & 1,00 & & & & & & \\
2. Örmögnunarröskun & 0,72 & 1,00 & & & & & \\
3. Ofálag & 0,53 & 0,47 & 1,00 & & & & \\
4. Vöxtur & $-0,39$ & $-0,34$ & $-0,22$ & 1,00 & & & \\
5. Stuðningur & $-0,38$ & $-0,32$ & $-0,20$ & 0,52 & 1,00 & & \\
6. Ööryggi & 0,17 & 0,12 & $-0,14$ & $-0,13$ & $-0,25$ & 1,00 & \\
7. Framgangur & $-0,27$ & $-0,28$ & $-0,28$ & 0,31 & 0,32 & $-0,11$ & 1,00 \\
\hline
\end{tabular}

Fylgnistuðlarnir eru allir marktækir miðað við $p<0,05(N=515)$.

Í töflu 6 sjást niðurstöður úr aðhvarfsgreiningu sem metur tengsl starfsaðstæðna, p.e. fimm kvarðar (JDRS) við tilfinningaprot Maslach annars vegar og örmögnunarröskun hins vegar. Eins og fram kemur í töflu 6 skýra starfsaðstæður um 39\% af dreifingu tilfinningaprots (Maslach) og 29\% af dreifingu örmögnunarröskunar (KEDS). Staðlaðar hallatölur ( $\beta$ ) leiða í ljós að ofálagskvarði JDRS sýnir sterkust tengsl einstakra pátta við bæði tilfinningaprot og örmögnunarröskun, vöxtur í starfi og stuðningur stofnunar hefur neikvæð en minni tengsl (marktæk) við kulnun og framgangur einnig við KEDS. Dað virðist pví vera að álagspættir hafi mest áhrif á tilfinningaprot og örmögnun en möguleikar til vaxtar og stuðningur í starfi virki verndandi.

Tafla 6. Tengsl tilfinningaprots og örmögnunarröskunar við fimm pætti starfsumhverfis.

\begin{tabular}{|c|c|c|c|c|c|c|c|c|c|c|}
\hline & \multicolumn{5}{|c|}{ Tilfinningaprot } & \multicolumn{5}{|c|}{ Örmögnun } \\
\hline & B & $\begin{array}{c}95 \% \\
\text { öryggisbil B }\end{array}$ & $\beta$ & $\mathrm{t}$ & $\mathrm{p}$ & B & $\begin{array}{c}\text { 95\% } \\
\text { öryggisbil B }\end{array}$ & $\beta$ & $\mathrm{t}$ & $\mathrm{p}$ \\
\hline Fasti & 13,04 & $3,76-22,30$ & & 2,76 & 0,01 & 13,24 & $4,55-21,93$ & & 2,99 & 0,00 \\
\hline Ofálag & 1,45 & $1,21-1,68$ & 0,45 & 12,17 & 0,00 & 1,07 & $0,85-1,30$ & 0,38 & 9,64 & 0,00 \\
\hline Vöxtur & $-0,69$ & $-0,97--0,40$ & $-0,20$ & $-4,71$ & 0,00 & $-0,49$ & $-0,76--0,22$ & $-0,16$ & $-3,60$ & 0,00 \\
\hline Stuðningur & $-0,27$ & $-0,31--0,11$ & $-0,17$ & $-4,10$ & 0,00 & $-0,14$ & $-0,23--0,46$ & $-0,13$ & $-2,93$ & 0,00 \\
\hline Óöryggi & $-0,18$ & $-0,19-0,55$ & 0,04 & 0,97 & 0,34 & 0,01 & $-0,34--0,35$ & 0,00 & 0,05 & 0,96 \\
\hline Framgangur & $-0,10$ & $-0,45-0,26$ & $-0,20$ & $-0,53$ & 0,59 & $-0,34$ & $-0,67--0,00$ & $-0,08$ & $-1,98$ & 0,05 \\
\hline Framgangur & $-0,10$ & $-0,45-0,26$ & $-0,20$ & $-0,53$ & 0,59 & $-0,34$ & $-0,67--0,00$ & $-0,08$ & $-1,98$ & 0,05 \\
\hline $\mathrm{R}^{2}$ leiðrétt & \multicolumn{5}{|c|}{$0,39 F(5,509)=65,57 p<0,001$} & \multicolumn{5}{|c|}{$0,29 F(5,509)=42,83 p<0,001$} \\
\hline
\end{tabular}

\section{Umræða}

Markmið pessarar rannsóknar var að kanna algengi kulnunar og tilfinningaprots hjá grunnskólakennurum, meta próun yfir tíma, bera saman við aðrar stéttir og kanna tengsl kulnunar við starfsaðstæður. Niðurstöðurnar sýna að tilfinningaprot meðal grunnskólakennara hefur aukist frá árunum 1999 og 2005. Á hinn bóginn er ekki að finna í niðurstöðum að grunnskólakennarar beiti varnarhætti hlutgervingar í meiri mæli en áður eða að mat á eigin starfsárangri hafi dvínað. Kulnun grunnskólakennara eins og hún birtist í tilfinningaproti hefur pannig aukist frá pví fyrir efnahagshrunið 2008. Rannsóknin sýnir jafnframt að 42\% grunnskólakennara eru yfir greiningarmörkum örmögnunarröskunar. Mat á starfsaðstæðum sýndi að grunnskólakennarar eru undir miklu álagi í starfi og koma fram sterk tengsl álags við bæði tilfinningaprot og örmögnunarröskun. Álag er pannig páttur í starfsumhverfi grunnskólakennara sem parf að gæta sérstaklega að. Af peim páttum sem kannaðir voru í pessari rannsókn pá sýndi ofálag, 
p.e. fjöldi verkefna, tímapressa, pörf fyrir stöðuga athygli og pað hversu persónuleg samskiptin eru við nemendur, mest tengsl við tilfinningaprot og örmögnunarröskun. Tækifæri til vaxtar, stuðningur frá stofnun og möguleikar til framgangs sýna minni tengsl en vísbending er um að petta séu verndandi umhverfispættir.

Nýlegar athuganir meðal grunnskólakennara gefa til kynna að álag skapist meðal annars vegna pess að grunnskólakennarar purfi að sinna enn fjölbreyttari nemendahópi en ádur (Ragnar F. Ólafsson, 2019). Dar má nefna ört vaxandi hóp barna af erlendum uppruna. Aðeins helmingur íslenskra kennara á unglingastigi telur sig geta sniðið kennslu sína að pörfum nemenda með ólíkan menningarlegan bakgrunn. Íslenskir kennarar eru líklegri en kennarar annars staðar á Norðurlöndum til að nefna að enn frekar purfi að auka stuðning við nemendur með erfiðan bakgrunn eða af erlendum uppruna og að leiðir til að mæta pörfum pess hóps purfi að vera forgangsverkefni í endurmenntun grunnskólakennara (Ragnar F. Ólafsson, 2019; Ragnar F. Ólafsson og Júlíus K. Björnsson, 2009).

Sömuleiðis hefur komið fram að pað að halda aga og stjórn í bekkjum veldur grunnskólakennurum álagi (Ragnar F. Ólafsson, 2019) og peir upplifa álag sem tengist nemendum með náms- eða hegðunarerfiðleika (Skúli Helgason o.fl., 2017). Parna mæðir mikið á grunnskólakennurum og breytingar eru hraðar en skólakerfið hefur ekki brugðist við með skilvirkum hætti. Hafa grunnskólakennarar verið að kalla eftir frekari aðstoð, til dæmis í formi endurmenntunar (Skúli Helgason o.fl., 2017; Ragnar F. Ólafsson, 2019). Mögulega setti hrunið strik í reikninginn hér pegar fjármagn var skorið niður og skólakerfið varð verr í stakk búið en ella til að bregðast við nýjum úrlausnarefnum tengdum auknum margbreytileika. Pá má ætla að mikið álag hafi verið á grunnskólakennurum um pó nokkurn tíma og ef til verið að safnast upp, og pað komi pá fram í auknum merkjum um tilfinningaprot.

Degar erfiðleikar tengjast hegðun nemenda í kennslustofum hefur komið fram að kennarar eru líklegri til að hverfa úr starfi (Cangelosi, 2004) og safngreining Aloe o.fl. (2014) sýndi fram á tengsl erfiðrar hegðunar og kulnunar hjá kennurum. Í íslenskri rannsókn fundust tengsl milli tilfinningaprots og pess að purfa að fást við erfið hegðunarvandamál (Snæfríður Björgvinsdóttir og Anna-Lind Pétursdóttir, 2014). Íslenskir kennarar á unglingastigi eru líklegri en kollegar peirra á Norðurlöndum að telja agavandamál vera til staðar, meiri tími virðist fara 1 að halda uppi aga og vinnufriði (Ragnar F. Ólafsson, 2019). Hér er greinilega viðfangsefni sem reynir á grunnskólakennara og parfnast frekari skoðunar. Bæði foreldrar og skólasamfélagið parf að leggja sig fram um góð og uppbyggileg samskipti en niðurstöður Ingvars Sigurgeirssonar og Ingibjargar Kaldalóns (2006) sýndu að jákvæð viðhorf til foreldra einkenndu pá skóla par sem hegðunarvandi var lítill. Í fyrri íslenskum rannsóknum kom fram að kennurum fyndist mikilvægt að finna fyrir stuðningi frá foreldrum (Anna Dóra Baldursdóttir, 2002), enda er hann lykill að lausn agavandamála.

Tilfinningaprot er kjarninn í starfstengdri kulnun samkvæmt Maslach og félögum (2001) en pað lýsir sér í pví að einstaklingur upplifir mikla streitu og streitueinkenni, par á meðal örmögnun, sem kemur fram í orkuleysi við að framkvæma daglegar athafnir. Í nýlegri rannsókn meðal grunnskólakennara í Bandaríkjunum kom í ljós að kvarðinn sem mælir tilfinningaprot og kvarðar sem mæla kvíða og punglyndi hafa álíka sterk tengsl við kvarða sem mæla væg geðræn einkenni. Pannig má ætla að ef tilfinningaprot mælist hátt geti pað, eins og ómeðhöndlaður langvarandi kvíði eða punglyndiseinkenni, próast yfir í alvarlegri og langvarandi geðræn einkenni ef ekki er gripið inn í (Schonfeld, Verkuilen og Bianchi, 2019). Dví er mikilvægt að grípa til aðgerða í starfsumhverfinu og takmarka streituvalda (Maslach o.fl., 2001). Niðurstöðurnar renna einnig stoðum undir upplýsingar frá VIRK sem gefa til kynna að stór hluti kennara leiti sér aðstoðar vegna kulnunar.

Rannsóknin hefur nokkra annmarka. Samanburður á premur páttum kulnunar við fyrri rannsóknir er birtur með peim fyrirvara að um kennara úr ólíkum sveitarfélögum er að ræða 
og úrtökin eru pví ekki að fullu sambærileg. Starfsaðstæður gætu verið ólíkar eftir stærð skóla, umgjörð, stefnu og stuðningi menntayfirvalda í ólíkum sveitarfélögum. Svarhlutfall er lægra en í fyrri rannsóknum og hefði mátt vera betra; pví er ekki hægt að útiloka að peir sem ekki svöruðu hefðu metið kulnun, örmögnunarröskun og starfsaðstæður með öðrum hætti. Á móti kemur að úrtakið virðist t.d. endurspegla vel kynjaskiptingu í pýði grunnskólakennara. Upplýsingar um vikmörk voru ekki gefnar í fyrri rannsóknum og pess vegna fæst ekki nákvæmt mat á pví hvort um tölfræðilega marktækar breytingar er að ræða. Aukning á tilfinningaproti er nokkuð afgerandi. Mæling á örmögnunarröskun gefur til kynna að stór hluti kennara sé við greiningarmörk og fleiri virðast komnir að polmörkum en er að merkja hjá félögum í BHM. Starfsaðstæður grunnskólakennara virðast meira ípyngjandi og mögulega minni stuðning að fá en hjá öðrum háskólamenntuðum opinberum starfsmönnum, m.a. framhaldsskólakennurum sem glíma síður við kulnun (Brynhildur Magnúsdóttir, 2012). Í rannsókninni var stuðst við mælitæki fyrir starfsaðstæður sem leyfir samanburð aðstæðna kennara við aðrar stéttir. Prátt fyrir að JDRS hafi upprunalega verið próaður til að meta starfsaðstæður kennara (Jackson og Rothmann, 2005) hefur ekki verið metið hversu vel hann endurspeglar aðstæður hérlendis.

Samanborið við rannsóknir Önnu Dóru og félaga sem gerðar voru í kringum aldamót og aftur stuttu fyrir hrun eru aukin einkenni tilfinningaprots mest áberandi. Sú breyting og hátt hlutfall grunnskólakennara yfir greiningarmörkum örmögnunarröskunar sýnir að leita parf allra leiða til að bæta starfsaðstæður í grunnskólum. Brýnast er að draga úr ofálagi sem skapast vegna fjölbreyttra og krefjandi verkefna. Auka parf tækifæri til vaxtar í starfi og huga að framgangsmálum. Kennarar purfa sífellt að fást við ný úrlausnarefni, hvort sem pað er ný tækni, breytt íbúasamsetning eða foreldrar sem gera aðrar kröfur en áður. Pað er ekki hægt að ætla peim að leysa pau öll. Í niðurstöðum TALIS er dregið fram að áberandi færri kennarar hér á landi en í öðrum pátttökulöndum telja að kennarastarfið sé mikils metið í pjóðfélaginu (Ragnar F. Ólafsson, 2019). Dað eitt og sér er áhyggjuefni. Dó kennarar finni fyrir stuðningi í skólanum pá virðist viðvarandi upplifun af virðingarleysi í samfélaginu og samskipti við foreldra skapa álag. Farsælt skólastarf er ekki einkamál starfsfólks skóla heldur samstarfsverkefni skóla, heimila og alls samfélagsins. Бað byggist meðal annars á virðingu fyrir fag- og sérfræðipekkingu kennara.

\section{Teachers' burnout and work demands: Comparison over time and to other public professionals.}

Teachers are among professionals exposed to burnout because of stressful working conditions. Previous results on burnout among compulsory school teachers in Iceland have shown that between the years 1999 and 2005 symptoms captured by the Maslach Burnout Inventory (MBI-ES) did not change extensively. Research indicates that the health and well-being of Icelandic compulsory teachers has deteriorated since the financial crisis in 2008. Financial cutbacks have resulted in lack of resources to tackle urgent challenges in schools such as meeting the needs of diverse student background, including behavioural and educational problems and multicultural issues. A shortage of compulsory-school teachers is a problem in Iceland and the number of teachers without certification working in compulsory schools is increasing. It is important in the light of the economic crisis and changes that have taken place in the school system and the foreseen shortage of compulsory teachers to evaluate burnout again as was the aim of this study. In addition, teachers' work environment has yet to be evaluated using known models for comparison to other professions.

In this study, burnout is captured using the MBI-ES as was done in previous studies in Iceland (Anna Dóra Baldursdóttir \& Valgerður Magnúsdóttir, 2007). Furthermore, the Karolinska Exhaustion Disorder Scale (KEDS) and JDRS (Job DemandsResources Scale) measuring work environment factors were used. Participants were 515 and the response rate was $38 \%$. Of participants $85 \%$ were female. 
Symptoms of emotional exhaustion on the MBE-ES scale had increased since before the economic crisis (from 1.5 to 2.4 on the original 6-point scale) while depersonalization and personal accomplishment had not. The teachers' averages on emotional exhaustion $(M=2.4)$ and personal accomplishment $(M=4.6)$ were high but low for depersonalization $(M=0.7)$, indicating that symptoms of burnout are mainly related to emotional exhaustion. On the KEDS scale, $42 \%$ of the participants met the criteria for exhaustion disorder which is higher than among members of the Icelandic Confederation of University Graduates where 38\% of those working as teachers in secondary schools, universities or in caregiving met the criteria, compared to $31 \%$ among those in other professions (e.g., architects, librarians, lawyers). Participants scored highest on job overload $(M=2.94)$ on the JDRS but also on the resources where they indicate they have good opportunities for growth $(M=2.92)$ and receive organizational support (2.95). Job insecurity $(M=1.52)$ is almost non-existent among compulsory school teachers and they also score low on advancement $(M=1.65)$. Results of the Pearson correlation indicated a strong positive association between Maslach's emotional exhaustion scale and exhaustion disorder (KEDS) $(r$ (515) $=$ $.72, p<0.001)$. A regression analysis with the factors from the JDRS as predictors for emotional exhaustion and exhaustion disorder respectively showed that work overload predicts higher scores, while opportunities for growth and organizational support predict lower scores. Together, the five factors from JDRS explain 39\% of the variance in emotional exhaustion and $29 \%$ of the variance in exhaustion disorder.

The study shows that symptoms of emotional exhaustion have increased among compulsory school teachers from previous studies while depersonalization and personal accomplishment stay at a similar level. While this is not a clear sign of occupational burnout according to the Maslach definition, the high scores of emotional exhaustion should not be overlooked as a high proportion of compulsory school teachers also meet the criteria for exhaustion disorder as defined by KEDS. To improve the wellbeing of compulsory school teachers and to prevent further development of burnout or exhaustion, job overload is a factor that needs to be considered. According to a recent study among compulsory teachers it is revealed that dealing with students' behavioral problems and their multicultural background as well as parental communication is causing strain. It is urgent to take action to increase resources for compulsory school teachers to tackle these challenges in order to lower their job overload. This needs to be dealt with at a high level so that proper resources, both financial and material can be added within the school system. If action is not taken, this can result in a worsening state of the teachers' health and well-being and even result in long term sickness absence or drop out from the profession.

Key words: Burnout, compulsory school teachers, work environment, health and well-being, exhaustion disorder, public professionals 


\section{Um höfundana}

Sif Einarsdóttir (sif@hi.is) er prófessor við námsbraut í náms- og starfsráđgjöf á Félagsvísindasviði Háskóla Íslands. Hún er með doktorsgráđu í ráđgefandi sálfræði frá University of Illinois, Champaign - Urbana. Hún hefur stundað rannsóknir á starfsáhuga fyrst og fremst en einnig á náms- og starfsferli ólíkra samfélagshópa.

Regína Bergdís Erlingsdóttir (rbe2@hi.is) lauk B.S.-prófi í sálfræði frá Háskóla Íslands og er með meistaragráðu í náms- og starfsráđgjöf frá Háskóla Íslands. Meistararitgerð hennar fjallaði um kulnun á meðal grunnskólakennara.

Amalía Björnsdóttir (amaliabj@hi.is) er prófessor við Deild heilsueflingar, íprótta og tómstunda á Menntavísindasviði Háskóla Íslands. Hún lauk B.A.-prófi í sálfræđi frá Háskóla Íslands, M.Sc.-prófi frá háskólanum í Oklahoma og doktorsprófi frá sama skóla. Hún hefur lagt stund á rannsóknir á sviði mælinga og prófagerðar, lestrar- og málproskamælinga, skólastjórnunar og áhrifa félagslegra pátta á skólastarf.

Ásta Snorradóttir (astasnorra@hi.is) er lektor við Félagsráđgjafardeild á Félagsvísindasviði Háskóla Íslands. Hún er með doktorsgrádu i félagsfræði frá Háskóla Íslands. Hún hefur lagt stund á rannsóknir á líðan og heilsu starfsfólks með sérstaka áherslu á áhrifapætti heilsu og líðanar í félagslegu vinnuumhverfi.

\section{About the authors}

Sif Einarsdóttir (sif@hi.is) is a professor in the School of Social Sciences at the University of Iceland. She is a Ph.D. graduate from the Counseling Psychology program at the University of Illinois, Champaign - Urbana. Her research has mainly focused on vocational interests, assessment and the career development of different social groups.

Regína Bergdís Erlingsdóttir (rbe2@hi.is) completed a B.S. degree in psychology from the University of Iceland and has an M.A. degree in career counseling and guidance from the University of Iceland. Her master's thesis was on burnout among schoolteachers.

Amalía Björnsdóttir (amaliabj@hi.is) is a professor at the School of Education, University of Iceland. She completed a B.A. degree in psychology from the University of Iceland and a Ph.D. from the University of Oklahoma. Her major research interests are in the areas of measurement and testing (reading and language development), school management and impacts of social factors on education.

Ásta Snorradóttir (astasnorra@hi.is) is an associate professor at the School of Social Sciences at the University of Iceland. She graduated with a Ph.D. in sociology from the University of Iceland. Her major research interests are on the psychosocial work environment and occupational health and well-being of employees.

Greinin er byggð á meistararitgerð Regínu Bergdísar Erlingsdóttur í MA námi í náms- og starfsráđgjöf við Háskóla Íslands. Við pökkum Félagi grunnskólakennara kærlega fyrir samstarfið við framkvæmd rannsóknar og peim sem gáfu sér tíma til að taka pátt. 


\section{Heimildir}

Aloe,A. M., Shisler, S. M., Norris, B. D., Nickerson,A. B. og Rinker,T.W. (2014).A multivariate meta-analysis of student misbehavior and teacher burnout. Educational Research Review, 12, 30-44. doi.org/10.1016/j. edurev.2014.05.003

Anna Póra Baldursdóttir. (2002). Kennarar og kulnun. Uppeldi og menntun, 11(1), 171-190. Sótt af http:// timarit.is/view_page_init.jsp?gegnirId=000604408

Anna Póra Baldursdóttir ogValgerður Magnúsdóttir. (2007). Líðan kennara í starfi - vinnugleði eða kulnun? Uppeldi og menntun, 16(1), 73-92.

Besér, A., Sorjonen, K., Whalberg, K., Petersen, U., Nygren, Å. og Åsberg, M. (2014). Construction and evaluation of a self-rating scale for stress-induced exhaustion disorder, the Karolinska Exhaustion Disorder Scale. Scandinavian Journal of Psychology, 55(1), 72-82. doi:10.1111/sjop.12088

Bianchi, R., Truchot, D., Laurent, E., Brisson, R. og Schonfeld, I. S. (2014). Is burnout solely job-related? A critical comment. Scandinavian Journal of Psychology, 55(4), 357-361. doi:10.1111/sjop.12119

Brynhildur Magnúsdóttir. (2012). Starf og lídan kennara í framhaldsskóla á höfuðborgarsvæðinu (óútgefin meistararitgerð). Háskóli Íslands, Reykjavík.

Cangelosi, J. S. (2004). Classroom management strategies: Gaining and maintaining students' cooperation. Hoboken, NJ:Wiley.

Demerouti, E., Bakker, A. B., Nachreiner, F. og Schaufeli,W. B. (2001). The job demands-resources model of burnout. Journal of Applied Psychology, 86(3), 499-512.

Freudenberger, H. J. (1974). Staff burn-out. Journal of Social Issues, 30(1), 159-165.

Gerður Ólína Steinpórsdóttir, Amalía Björnsdóttir og Börkur Hansen. (2015). Grunn- og leikskólastjórar á Íslandi - Kulnun í starfi? Uppeldi og menntun, 24(2), 33-56.

Geving, A. M. (2007). Identifying the types of student and teacher behaviours associated with teacher stress. Teaching and Teacher Education, 23(5), 624-640.

Gold, Y. og Roth, R. (1993). Teachers managing stress and preventing burnout. The professional health solution. London: Falmer Press.

Guðbjörg Linda Rafnsdóttir og Hjördís Sigursteinsdóttir. (2016). Veikindafjarvistir, læknisheimsóknir og vinnutengd líðan í kjölfar bankahruns. Samanburður á starfsfólki skóla og öðru starfsfólki sveitarfélaga. Netla-Veftímarit um uppeldi og menntun. Sótt af http://netla.hi.is/greinar/2016/ryn/08_ryn_arsrit_2016.pdf

Guðrún Ragnarsdóttir, Ásrún Matthíasdóttir og Jón Friðrik Sigurðsson. (2010).Velferð kennara er lykillinn að öflugum framhaldsskóla. Netla - Veftímarit um uppeldi og menntun. Sótt af http://netla.hi.is/greinar/2010/008/index.htm

Hagstofa Íslands. (2018). Starfsfólk við kennslu eftir kyni, réttindum, menntun og búsetu 1998-2018. Sótt af https://px.hagstofa.is/pxis/pxweb/is/Samfelag/Samfelag_skolamal_2_grunnskolastig_1_gsStarfsfolk/ SKO02302.px

Hagstofa Íslands. (2019a). Meðalaldur starfsfólks við kennslu 1998-2018. Sótt af https://px.hagstofa.is/ pxis/pxweb/is/Samfelag/Samfelag_skolamal_2_grunnskolastig__1_gsStarfsfolk/SKO02308.px/table/ tableViewLayout1/?rxid=1385cebc-3f17-4ad9-8bac-7a4923c74fa6

Hagstofa Íslands. (2019b). Starfsfólk við kennslu eftir kyni, aldri og réttindum 1998-2018. Sótt af https://px.hagstofa.is/pxis/pxweb/is/Samfelag/Samfelag_skolamal_2_grunnskolastig_1_gsStarfsfolk/SKO02303. px/table/tableViewLayout1/?rxid=c8f47513-6548-4ba4-929f-ab5e473eecb2

Hagstofa Íslands. (2019c). Grunnskólanemendur með erlent móðurmál 1997-2018. Sótt af https://px.hagstofa.is/pxis/pxweb/is/Samfelag/Samfelag_skolamal_2_grunnskolastig_0_gsNemendur/SKO02103. px/table/tableViewLayout1/?rxid=f1102feb-2a7d-44d4-b7af-79ee70d35c2b

Hakanen, J. J., Schaufeli, W. B. og Ahola, K. (2008). The job demands-resources model: A three-year crosslagged study of burnout, depression, commitment, and work engagement. Work and Stress, 22(3), 224-241. doi:10.1080/02678370802379432

Hasselberg, K., Jonsdottir, I. H., Ellbin, S. og Skagert, K. (2014). Self-reported stressors among patients with exhaustion disorder:An exploratory study of patient records. BMC Psychiatry, 14(1), 66. doi:10.1186/1471244X-14-66 
Hattie, J. (2009). Visible learning: A synthesis of over 800 meta-analyses relating to achievement. London: Routledge.

Helgi Eiríkur Eyjólfsson og Stefán Hrafn Jónsson. (2017). Skýrsla til starfshóps um nýliðun og batt starfsumhverfi grunnskólakennara í Reykjavík: Könnun á meðal útskriftarárganga úr kennaranámi HÍ/KHÍ og HA árin 2000-2012. Reykjavík: Rannsóknarsetur í mannfjöldafræðum.

Ingvar Sigurgeirsson og Ingibjörg Kaldalóns. (2006). Gullkista við enda regnbogans: Rannsókn á hegðunarvanda i grunnskólum Reykjavíkur skólaárið 2005-2006. Reykjavík: Rannsóknarstofnun Kennaraháskóla Íslands.

Jackson, L. T. B. og Rothmann, S. (2005). Work-related well-being of educators in a district of the North West Province. Perspectives in Education, 23(3), 107-122.

Jeynes, W. H. (2005). A meta-analysis of the relation of parental involvement to urban elementary school student achievement. Urban Education, 40(3), 237-269.

Johnston, S. (2012). Administrative supports that reduce teacher stress (doktorsritgerð).Vancouver Island University, Nanaimo.

Kahn, J. H., Schneider, K.T., Jenkins-Henkelman, T. M. og Moyle, L. L. (2006). Emotional social support and job burnout among high-school teachers: Is it all due to dispositional affectivity? Journal of Organizational Behaviour, 27(6), 793-807.

Kristensen, T. S., Borritz, M.,Villadsen, E. og Christensen, K. B. (2005).The Copenhagen Burnout Inventory: A new tool for the assessment of burnout. Work \& Stress, 19(3), 192-207.

Kristín Jónsdóttir og Amalía Björnsdóttir. (2014). Foreldrasamstarf. Í Gerður G. Óskarsdóttir (ritstjóri), Starfshattir í grunnskólum við upphaf 21. aldar (bls. 197-216). Reykjavík: Háskólaútgáfan.

Lög um grunnskóla nr. 91/2008.

Lög um persónuvernd og vinnslu persónuupplýsinga nr. 90/2018.

Maslach, C. (1976). Burned-out. Human Behavior, 5, 16-22.

Maslach, C. (1993). Burnout:A multidimensional perspective. Í W. B. Schaufeli, C. Maslach og T. Marek (ritstjórar), Professional burnout, recent developments in theory and research (bls. 19-32). Philadelphia, PA: Taylor \& Francis.

Maslach, C., Jackson, S. E. og Leiter, M. P. (1986). Maslach burnout inventory. Palo Alto, CA: Consulting Psychologists Press.

Maslach, C., Jackson, S. E. og Leiter, M. P. (1997). Maslach burnout inventory. Í C. P. Zalaquett og R. J.Wood (ritstjórar), Evaluating stress: A book of resources (bls. 191-218). Lanham, MD: Scarecrow Education.

Maslach, C., Jackson, S. E. og Schwab, R. L. (1986). Maslach burnout inventory-Educators survey. Mind Garden. Sótt af https://www.mindgarden.com/316-mbi-educators-survey

Maslach, C. og Leiter, M. P. (2016). Understanding the burnout experience: Recent research and its implications for psychiatry. World Psychiatry, 15(2), 103-111. https://doi.org/10.1002/wps.20311

Maslach, C., Leiter, M. P. og Schaufeli,W. B. (2008). Measuring burnout. Í C. L. Cooper og S. Cartwright (ritstjórar), The Oxford handbook of organizational well-being (bls. 86-108). Oxford: Oxford University Press.

Maslach, C., Schaufeli, W. B. og Leiter, M. P. (2001). Job burnout. Annual Review of Psychology, 52, 397-422.

Mennta- og menningarmálaráðuneyti. (2011). Aðalnámskrá grunnskóla:Almennur hluti 2011. Reykjavík: Höfundur.

Mennta- og menningarmálaráđuneytið. (2019). Stóraukin aðsókn í kennaranám: Nýnemadagar á Menntavísindasviði HÍ. Sótt af https://www.stjornarradid.is/efst-a-baugi/frettir/stok-frett/2019/08/27/Storaukin-adsokn-i-kennaranam-Nynemadagar-a-Menntavisindasvidi-HI-/

Pyhältö, K., Pietarinen, J. og Salmela-Aro, K. (2011). Teacher-working-environment fit as frame for burnout experienced by Finnish teachers. Teaching and Teacher Education, 27, 1101-1110. doi:10.1016/j.tate.2011.05.006

Ragnar F. Ólafsson. (2019). TALIS 2018: Starfshettir og viðhorf kennara og skólastjóra á unglingastigi grunnskóla. Reykjavík: Menntamálastofnun.

Ragnar F. Ólafsson og Júlíus K. Björnsson. (2009). TALIS: Staða og viðhorf kennara og skólastjórnenda: Teaching and Learning International Study: Albjóðleg samanburðarrannsókn unnin í samvinnu við OECD fyrir menntamálaráduneytið. Reykjavík: Námsmatsstofnun.

Rothmann, S., Mostert, K. og Strydom, M. (2006). A psychometric evaluation of the job demands-resources scale in South Africa. Journal of Industrial Psychology, 32(4), 76-86. doi:10.4102/sajip.v32i4.239 
Samband íslenskra sveitarfélaga. (2012/2013). Sameiginleg könnun Sambands íslenskra sveitarfélaga og Félags grunnskólakennara. Reykjavík: Höfundur.

Schonfeld, I. S., Verkuilen, J. og Bianchi, R. (2019). An exploratory structural equation modeling bi-factor analytic approach to uncovering what burnout, depression, and anxiety scales measure. Psychological Assessment, 31(8), 1073-1079. doi:10.1037/pas0000721

Skaalvik, E., M. og Skaalvik, S. (2010). Teacher self-efficacy and teacher burnout:A study of relations. Teaching and Teacher Education, 26(4), 1059-1069. doi:10.1016/j.tate.2009.11.001

Skúli Helgason, Rósa Ingvarsdóttir, Ólafur Loftsson, Hildur Ingólfsdóttir, Jónína Vala Kristinsdóttir, Eygló Friðriksdóttir, .. Svandís Ingimundardóttir. (2017). Nýliðun og bætt starfsumhverfi grunnskólakennara. Sótt af https://reykjavik.is/sites/default/files/ymis_skjol/skjol_utgefid_efni/skrsla.pdf.pdf

Snæfríður Björgvinsdóttir og Anna-Lind Pétursdóttir. (2014). Erfið hegðun nemenda:Áhrifá líðan kennara. Uppeldi og menntun, 23(2), 65-86.

Steinunn Helga Lárusdóttir, Anna Kristín Sigurðardóttir, Arna H. Jónsdóttir, Börkur Hansen og Guðný Guðbjörnsdóttir. (2015). Efnahagshrunið og skólastarfí Reykjavík. Netla-Veftímarit um uppeldi og menntun. Sótt af http://netla.hi.is/greinar/2015/ryn/004.pdf

Pórey Pormar. (2018). The relationship between exhaustion, work-related experience and working conditions among employees in different occupations (óútgefin meistararitgerð). Háskólinn í Reykjavík, Reykjavík.

Sif Einarsdóttir, Regína Bergdís Erlingsdóttir, Amalía Björnsdóttir og Ásta Snorradóttir (2019).

Kulnun kennara og starfsaðstæður: Próun og samanburður við aðra opinbera sérfræðinga

Netla - Veftímarit um uppeldi og menntun. Menntavísindasvið Háskóla Íslands.

Sótt af http://netla.hi.is/greinar/2019/ryn/12

DOI: https://doi.org/10.24270/netla.2019.12 